ENTITA : Jurnal Pendidikan IImu Pengetahuan Sosial dan IImu-IImu Sosial

Vol.3 No.2, December 2021

ENTITA : Jurnal Pendidikan Ilmu Pengetahuan Sosial dan Ilmu-Ilmu Sosial http://ejournal.iainmadura.ac.id/index.php/entita

P-ISSN:2715-7555 E-ISSN:2716-1226

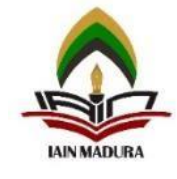

\title{
Konstruksi Belajar Multi Arah pada Implementasi Model Merdeka Belajar dan Kampus Merdeka (Learning Analysis of How to Learn based on Self Awareness)
}

\author{
Saiful Hadi \\ (Institut Agama Islam Negeri Madura) \\ saifulhadi.rachman@gmail.com
}

Abstract

Construction of multi direction which initiates students' involvement by self-directed, collaborative, and institutional as learning approach, oriented on the effort of improving graduates capacity in which be able to apply their own knowledge and practical skill experience in working world that take advantage of wide learning source with learning model of research or inquiry through merdeka belajar dan kampus merdeka model, based on institution characteristics that its curriculum ignites the pattern of multi direction learning. Therefore, the students can analyze learning how to learn based on their learning needs. Implementation of multi direction strategy needs curriculum design of college that is adaptive suitable with the demands of contemporary regulation change and future needs which states in design of kurikulum kualifikasi nasional Indonesia (KKNI). The impact of construction multi direction implementation is employment skill and enterpreneurship based on community character values which are available in society life civilization. Employment skill dan entrepreneurship contain critical thinking element which grows students that have self capacity appearing in themselves that are able to think critically, think creatively, communicate effectively with other people and collaborate with colleague or tim work. Keywords: learning how to learn, enquiry/research, critical thinking

\section{Abstract}

Konstruksi belajar multi arah yang menggagas keterlibatan mahasiswa secara self-directed, collaborative, and institutional mode sebagai pendekatan pembelajaran, berorientasi pada upaya meningkatkan kapasitas lulusan yang mampu mengaplikasikan bidang keilmuan dan pengalaman skill praktis dalam dunia kerja yang memanfaatkan sumber belajar yang luas dengan model pembelajaran research atau inquiry atau melalui model merdeka belajar dan kampus merdeka, sesuai dengan karakteristik institusi yang desain kurikulumnya memantik terjadinya pola pembelajaran multi arah dan mahasiswa mampu menganalisis learning how to learn nya sesuai dengan kebutuhan belajar mahasiswa. Implementasi strategi pembelajaran multi arah membutuhkan desain kurikulum pendidikan tinggi yang adaptif sesuai dengan tuntutan perubahan regulasi kekinian dan kebutuhan masa depan sebagaimana dalam desain kurikulum kualifikasi nasional Indonesia (KKNI). Dampak implementasi konstuksi pembelajaran multiarah salah satu diantara bentuk hasil pembelajaran yang dilakukan mahasiswa yaitu employment skill dan enterprneur berlandaskan nilai-nilai karakter komunitas yang ada dalam peradaban kehidupan masyarakat. Employment skill dan entrepreneur di dalamnya mengandung unsur critical think yang menumbuhkan mahasiswa memiliki kapasitas diri yang nampak dalam diri mahasiswa yaitu mampu: berfikir kritis, berfikir kreatif, berkomunikasi efektif dengan orang lain, dan berkolaborasi bersama kolega atau tim kerja.

Kata Kunci: learning how to learn, enquiry/research, critical thinking 


\section{Pendahuluan}

Membincangkan tema implementasi merdeka belajar kampus merdeka di era new normal, perlu melakukan pemahaman secara terstruktur pola belajar setiap individu menurut pandangan filsafat pendidikan khususnya bagi orang dewasa. Mahasiswa adalah manusia dewasa awal dalam proses transisinya dari remaja akhir menuju ke usia dewasa, dan salah satu diantara ciri kedewasaannya adalah memulai diri berfikir untuk menentukan dan mengambil keputusan untuk memenuhi kebutuhan belajarnya, dengan kata lain mahasiswa dengan tingkat kedewasaannya memiliki perkembangan psikologis yaitu berfikir logis. Pikiran logis mahasiswa sebagai diri orang dewasa seharusnya dapat memulai self-planed atau self-directed, bahwa keseluruhan pengalaman belajar yang dilakukan oleh individu terhadap obyek yang dipelajari, mereka melakukan tiga hal: a) self determination, b) self actualization, dan c). self transformation, ".(Peter Jarvis \& John Holford, Collin Griffin, 1988). Pokok pikiran tentang merdeka belajar hakekatnya mengacu pada aspek utama dalam pembelajaran yaitu "individu pembelajar" yang memiliki otonomi dalam memperoleh pengetahuan diri, keterampilan dasar, dan pemahaman umum dalam menghadapi tuntutan kehidupan sehari-hari, 1) ketika berada di lingkungan kampus seperti; prestasi belajar, pengembangan budaya akademik, dan tuntutan kehidupan kampus lainnya atau 2) individu telah selesai belajar (berada di tengah-tengah masayarakat) seperti; kemampuan adaptasi dengan lingkungan sekitar, mampu bersaing dengan sesama di lingkungannya, dan mampu memenuhi kebutuhan hidup diri dan tanggungjawab sosialnya.

Konstruksi belajar pada setiap individu mengutip Cyril Houle`s dalam penelitiannya, sebagaimana dikutip dapat mengkategorikan menjadi tiga kelompok yaitu: a) goal oriented yaitu motivasi belajar yang dilakukan seseorang merupakan sarana untuk mencapai tujuan tertentu seperti karir profesional, b) activity oriented yaitu motivasi belajar seseorang ingin melakukan interaksi dan kegiatan sosial yang ditawarkan di sekolah, c) learning oriented, yaitu motivasi belajar individu dalam rangka memenuhi 258 
kebutuhan belajarnya, ".(Direktorat Jendral Pendidikan Tinggi Kementerian Pendidikan dan Kebudayaan, 2020).

\section{Konsep Dasar Belajar Multi Arah}

Belajar multi arah hakekatnya adalah proses belajar yang dilakukan oleh individu atau mahasiswa dengan memanfaatkan berbagai sumber belajar yang dibutuhkan, baik yang tersedia langsung di lingkungan tempat belajarnya, atau sumber belajar yang ada di luar lingkungan tempat belajar baik yang tersedia secara on line ataupun tersedia dalam bentuk cetak. Ramli Abdullah mengutip pendapat Percival dan Ellington menjelaskan :" sumber belajar dari sisi pembuatan adalah seperangkat bahan atau situasi belajar yang dengan sengaja atau tidak sengaja diciptakan agar peserta didik secara individual dan atau secara bersama-sama dapat belajar ".(Ramli Abdullah, 2012: 216-231).

Belajar multi arah dengan memanfaatkan sumber, tidak hanya terbatas pada buatan saja akan tetapi meminjam pendangan dari Seels dan Richey menjelaskan bahwa sumber belajar adalah:" segala sumber pendukung untuk kegiatan belajar, termasuk sistem pendukung dan materi serta lingkungan pembelajaran ". (B. Seels \& Richey, R.C, 1994: 65-66). Termasuk juga sistem pembelajaran merdeka yang sedang ramai diperbincangkan pada masayarakat pembelajar, dengan kata lain belajar multi arah perlu diciptakan sistemnya, apakah pada level dosen atau pada level institusi.

Individu atau mahasiswa ketika melakukan kegiatan pembelajaran tidak hanya terpaku saat ada di lingkungan kampus atau sekolah, akan tetapi mereka dapat melakukan kegiatan belajarnya di rumah, di kantor, di tempat ibadah, atau di masyarakat luas. Secara teoritik keluasan tempat atau lokasi belajar didasarakan atas klasifikasi sumber belajar yang meliputi: a) pesan, merupakan informasi yang disampaikan orang sumber, b) bahan, yang merupakan kelompok alat yang disebut dengan perangkat lunak, c) alat, yang sering disebut dengan perangkat keras, d) teknik, yang merupakan prosedur baku berupa pedoman langkah langkah dalam penyampaian pesan, e) latar, merupakan lingkungan tempat penyampaian pesan, (Yusuf Hadi Miarso, 2005: 240).

Belajar multi arah yang disebut dalam tema diskusi ini hakekatnya memetakan sumber belajar yang digunakan oleh pengajar atau dosen bersama mahasiswa dalam 
rangka memperkuat hasil belajar mahasiswa, yaitu 1) memperkuat pola belajar mandiri self directed leraning sehingga memungkinkan mahasiswa lebih bergairah belajarnya, 2) memperkuat produktifitas belajar, sebab sumber belajar baik varian bahan dan lokasi belajar sangat membantu mahasiswa memperkaya informasi pengetahuan dan pengalaman yang lebih banyak, 3) memungkinkan kegiatan pembelajaran yang dilakukan bersama mahasiswa lebih scientific, karena dapat didesain menjadi lebih inquiry atau discovery, 4) informasi hasil belajar yang diperoleh anak didik (mahasiswa) lebih konkrit karena sumber belajar yang digunakan berada di lokasi sumber yang dibutuhkan oleh mahasiswa, mengurangi kegiatan belajar yang bersifat verbal di kelas menuju pembelajaran yang lebih riil di sumber belajar yang ada, 5) memungkinkan kegiatan belajar mengjakau sumber yang lebih luas, sebab informasi yang digunakan memungkinkan meluas di luar batas geografis, dan banyaknya sumber-sumber yang terlibat dalam pembelajaran bersama mahasiswa.

Konsep dasar pembelajaran multi arah hakekatnya didasari oleh model pembelajaran yang dikembangkan oleh Blaney (1974) yang dikutip oleh Robert M. Smith yang dinyatakan bahwa proses belajar yang dilakukan dalam kegiatan pendidikan adalah memadukan tiga model atau strategi atau konteks yaitu:" self directed, collaborative, and institutional mode". (Robert M. Smith, 1982:22) Ketiga model pembelajaran ini jika diimplementasikan secara simultan maka dapat mendasari proses belajar multi arah seriap individu atau mahasiswa, dan memungkinkan sekali setiap mahasiswa mampu melakukan kegiatan pembelajaran yang benar-benar merdeka.

Model atau strategi self directed learning adalah strategi belajar yang menempatkan mahasiswa sebagai pusat belajar atau student center learning bahwa mahasiswa senantiasa melakukan perencanaan untuk menentukan apa, kapan, dimana, dan bagaimana mereka belajar, khususnya terkait: a) tujuan belajar yang ingin dicapai, b) cara menemukan sumber belajar, memilih dan mengimplementasikan strategi belajar yang diinginkan. Tugas fasilitator atau dosen cukup memberikan pengarahan pokok pikiran sesuai dengan target kurikulum yang telah ditetapkan.

Model atau strategi collaborative learning yaitu model pembelajaran kelompok yang memungkinkan setiap individu memiliki keragaman pengalaman, dan keahlian 260 
anggota kelompok tersebut untuk menyelesaikan tugas dan mencapai tujuan belajarnya, meski ada perbedaan mendasar dengan model koopertatif. Jika model atau strategi kooperatif lebih mengutamakan kesamaan persepsi dalam menyelesaikan tugas dan mencapai tujuan kelompok, sedangkan model kolaboratif mengutamakan variasi atau ragam persepsi dalam menyelesaikan tugas kelompok.

Model atau strategi institusional, kegiatan pembelajaran berdasar pada program insttitusi. Model kegiatan belajar dilakukan di kelas pada sebuah perguruan tinggi, tempat kursus atau tempat kerja lainnya, bahwa beban kredit dari suatu pengetahuan dan capaian tujuan profesi yang diinginkan menjadi aspek utama yang harus diperhatikan setiap individu.

Diantara bentuk belajar yang dapat dilakukan oleh individu yaitu memenuhi pedoman belajar yang dibuat institusi seperti; membuat laporan pengalaman lapangan, essae, membuat catatan perkembangan belajar, mengatasi problema-problema belajar yang ditugaskan institusi, baik ketika belajar di lokasi tempat sendiri atau ketika belajar di tempat lainnya.

Ketiga model belajar tersebut baik self directed learning, collaborative, and institutional mode yang dipilih dan diimplementasikan dalam kegiatan pembelajaran dapat dilihat capaian pembelajaran yang diinginkan:

\section{Tabel 1: Sinergitas Model Pembelajaran dan Capaian Tujuan Belajar}

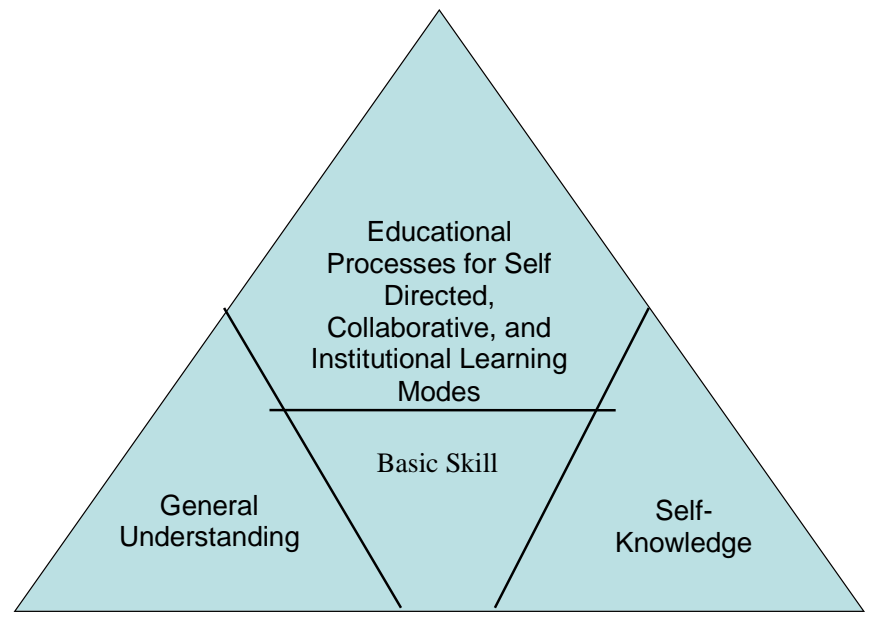

Capaian belajar ada pada 3 komponen hasil: a) general understanding, b) basic skill, dan c) self knowledge 
Konstruksi belajar multi arah dengan memanfaatkan sumber belajar yang lebih variatif, bahwa belajar tidak hanya terkungkung pada satuan pendidikan yang ada, maka hasil belajar yang akan dicapai adalah: a) general understanding, yaitu beragam pengetahuan yang dapat membantu menyediakan landasan yang kokoh terhadap attitude yang positif, dan motivasi kebutuhan belajarnya. Dengan kata lain:"... mahasiswa memeiliki kemampuan dan tanggungjawab merencanakan sebanyak kebutuhan belajarnya sendiri, (Jerold W. Apps, 1979: 1). b) basic skill, keterampilan dasar yaitu seseorang mempelajari hal hal yang berharga tidak hanya sebatas melalui menelaah, mendiskripsi, dan membuat proyeksi, namun bisa melalui mendengar dan mengamati lingkungan belajar sekitarnya. Lingkungan belajar adalah sebagian sumber belajar yang berharga, salah satu diantara contohnya belajar sebagai operator computer, maka akan mendapatkan keterampilan dasar "computer literacy" bermanfaat untuk belajar dan bekerja.(Robert M. Smith, 1982: 21). c) self knowledge, yaitu pengetahuan diri yang bermanfaat untuk membangun kesadaran dan pemahaman terhadap hambatan dan kesulitan belajar yang dihadapi, contohnya hambatan memperoleh akses sumber belajar di tempat lain, hambatan besarnya biaya yang harus dikeluarkan, dll.

Belajar multi arah dengan menggunakan ketiga model belajar tersebut di atas, implikasi dan aplikasinya dalam membangun kesadaran belajar mahasiswa dapat dilihat pada tabel berikut:

Tabel 2: Analisa Karakteristik Belajar Multi Arah Aplikasi Tiga Model Pembelajaran dalam Kontek Merdeka Belajar

\begin{tabular}{|c|c|c|c|c|c|}
\hline \multirow[t]{2}{*}{ NO. } & \multirow[t]{2}{*}{$\begin{array}{l}\text { MODEL } \\
\text { BELAJAR }\end{array}$} & \multirow{2}{*}{\multicolumn{2}{|c|}{$\begin{array}{c}\text { LEVEL } \\
\text { PENGAMBIL } \\
\text { KEPUTUSAN }\end{array}$}} & \multicolumn{2}{|c|}{$\begin{array}{l}\text { KOMPOSISI KOTRIBUSI MERDEKA BELAJAR DAN } \\
\text { MERDEKA KAMPUS }\end{array}$} \\
\hline & & & & Merdeka Belajar & Kampus Merdeka \\
\hline 1. & $\begin{array}{l}\text { Self Directed } \\
\text { Learning }\end{array}$ & $\begin{array}{l}\text { Dosen/ } \\
\text { Fasiltator } \\
\text { Mahasiswa }\end{array}$ & \& & $\begin{array}{l}\text { Dosen mendorong } \\
\text { mahasiswa untuk } \\
\text { melakukan } \\
\text { pembelajaran secara } \\
\text { otonom/individual } \\
\text { sesuai dengan } \\
\text { kebutuhan } \\
\text { belajarnya }\end{array}$ & - \\
\hline 2. & $\begin{array}{l}\text { Collaborative } \\
\text { Learning }\end{array}$ & $\begin{array}{l}\text { Dosen/ } \\
\text { Fasilitator } \\
\text { Mahasiswa }\end{array}$ & \& & $\begin{array}{l}\text { Dosen mendorong } \\
\text { mahasiswa untuk } \\
\text { melakukan } \\
\text { pembelajaran secara } \\
\text { kolaboratif sesuai }\end{array}$ & - \\
\hline
\end{tabular}




\begin{tabular}{|c|c|c|c|c|}
\hline & & & $\begin{array}{l}\text { dengan ragam } \\
\text { kebutuhan } \\
\text { belajarnya dalam } \\
\text { kelompoknya }\end{array}$ & \\
\hline 3. & $\begin{array}{l}\text { Institutional } \\
\text { Mode }\end{array}$ & $\begin{array}{l}\text { Institusi/ } \\
\text { Kelembagaan }\end{array}$ & - & $\begin{array}{l}\text { Institusi membangun sistem } \\
\text { dengan regulasi akademik untuk } \\
\text { memenuhi kebutuhan internal dan } \\
\text { fasilitasi eksternal kampus }\end{array}$ \\
\hline
\end{tabular}

\section{Diskursus Pola Belajar Multi Arah sebagai Representasi Merdeka Belajar dan Konstruksi Isi Kurikulum}

Membahas tentang proses belajar setiap individu, yang menjamin kemerdekaan belajar dalam suasana (lingkungan) belajar pun merdeka bergantung pada konstruksi kurikulum yang didesain oleh lembaga pendidikan itu sendiri, sebab konstruksi kurikulum merupakan karakteristik yang menjadi penanda bahwa suasana akademik menunjukkan individu (mahasiswa) dan/atau sivitas akademika memiliki kesadaran diri belajar lebih independen.

Independensi pembelajaran yang dilakukan oleh mahasiswa (individu) menunjukkan bahwa: inisiasi pembelajaran yang merdeka hakikatnya memberikan kesempatan yang luas kepada mahasiswa untuk selalu self learning, collaborative learning, and institutional mode merupakan inti kegiatan belajar yang lebih merdeka, karena mereka tidak terlalu bergantung pada fasilitator atau dosen sebagi pembimbing sebagai penganpu matakuliah yang telah ditentukan akademik. Tuntutan merdeka belajar sebagimana dikemukakan pada buku pedoman tentang merdeka belajar dikutib dari Peraturan Pemerintah tentang Standar Nasional Pendidikan Tinggi bahwa: sesuai dengan standar pembelajaran yaitu a) mahasiswa belajar sesuai masa studi dan beban belajar pada program studi pada perguruan tingginya, b) mahasiswa belajar di program studi untuk memenuhi sebagian masa dan beban belajar, dan sisanya belajar belajar mengikuti pembelajaran diluar program studi . Mencermati konsep merdeka belajar maka sangat memungkinkan setiap mahasiswa memiliki harapan yang besar untuk memperoleh kesempatan yang disediakan perguruan tinggi: a) pembelajaran yang lebih otonom dan fleksibel, b) merasakan adanya kultur belajar yang inovatif, tidak mengekang dan sesuai dengan kebutuhana belajar mahasiswa." (Mamat Burhanuddin, 2020: 6). 
Representasi belajar multi arah dalam konsep merdeka belajar hakekatnya merupakan implementasi strategi pembelajaran yang dirancang oleh institusi pendidikan, dan merupakan jabaran kegiatan pembelajaran yang didesain dosen/fasilitator untuk mengembangkan isi kurikulum yang mampu memberikan arah tujuan pembelajaran atau kompetensi yang diinginkan oleh mahasiswa.

Kompetensi yang dirumuskan sebagai arah capaian tujuan pembelajaran pada setiap PTKI, maka kurikulum pendidikan seharusnya dituntut untuk mampu menopang proses kegiatan belajar individu terhadap: a) capaian learning outcome, b) profil lulusan yang terdiri dari profil utama, profl pendukung, dan profil lainnya. Kegiatan profil tersebut secara simultan menjadi karakter atau penciri program studi yang secara terus menerus disosialisasikan kepaa berbagai pihak, sehingga menjadi habituasi yang dikembangkan dalam kegiatan pembelajaran.

Desain isi kurikulum pendidikan dalam rangka memenuhi kebutuhan belajar mahasiswa, maka setiap desainer harus memilih pendekatan yang tepat sehingga pembelajaran yang dilakukan sesuai dengan isi kurikulumnya. Beberapa pendekatan dalam mendesain kurikulum pendidikan yang memungkinkan dapat mendorong terjadinya proses pembelajaran secara multi arah sebagai penanda terjadinya merdeka belajar dapat diamati sebagaimana tabel berikut.

\section{Tabel 3: Pendekatan Desain Kurikulum Pembelajaran Merdeka}

\begin{tabular}{|c|c|c|}
\hline No. & Pendekatan & Keterangan \\
\hline 1. & Curricullum for survival & $\begin{array}{l}\text { Pengetahuan untuk a) mengetahui ketrampilan kerja, b) } \\
\text { mengetahui bagaimana cara memperoleh pendapatan, c) } \\
\text { keterampilan yang berhubungan dengan pasangan hidup, } \\
\text { anak-anak, dan rekan kerja, d) mampu mengisi kehidupan } \\
\text { dunia yang dibutuhkan, e) mengetahui cara bersaing di pasar } \\
\text { kerja }\end{array}$ \\
\hline 2. & Curricullum for meaning & $\begin{array}{l}\text { a) pengetahuan yang dapat membantu memperoleh makna } \\
\text { kehidupan sehari-hari tidak hanya menjadikan ilmuwan namun } \\
\text { juga menjadi humanis b) menjadikan pribadi seseorang yang } \\
\text { bijaksana sesuai dengan tuntutan budaya masyarakat } \\
\text { setempat (=Indonesia nasionalis-religius) }\end{array}$ \\
\hline 3. & $\begin{array}{l}\text { Curriculum for learning to } \\
\text { learn }\end{array}$ & $\begin{array}{l}\text { Pengetahuan digunakan a) seseorang yang learning how to } \\
\text { learn terfokus pada penyelesaian masalah yang dihadapi } \\
\text { melalui belajar bermacam-macam keterampilan dasar } \\
\text { penyelesaian masalah, b) learning how to learn di luar } \\
\text { permasalahan yang dihadapi seperti "lumbung pangan", maka } \\
\text { dapat belajar melalui literatur, wawancara dengan petani, atau } \\
\text { kunjungan ke tempat lumbung pangan yang dikelola } \\
\text { masyarakat c) learning how to learn sesuatu yang menarik }\end{array}$ \\
\hline
\end{tabular}



4. Curriculum for helping
communities provide a humane environment
perhatian seperti kemerdekaan bangsa. Tipe kurikukum pola belajar self directed yang luas sekali.
Pengetahuan tentang psikologi, sosiologi, dan politik, pada dasarnya suatu pengetahuan untuk melakukan perubahan sosial yang terjadi di masyarakat.

Salah satu contoh desain pendekatan "curriculum for survival Rusman menyebut dengan istilsh activity curriculum bahwa: desain kurikulum yang isinya banyak menuntut kegiatan mahasswa untuk membentuk kemampuan yang terintegrasi dengan lingkugan maupun dengan potensi mahasiswa itu sendiri, mahasiswa melakukan aktifitas yang sifatnya vocational, akan tetapi tidak meninggalkan aspek intelektual atau akademik mahasiswa.(Rusman, 2008: 69) atau pendekatan yang lain yaitu curriculum for learning to learn, desain pendekatan ini menguatamakan aktifitas belajar mahasiswa diarahkan memiliki pengetahuan dan pengalaman belajar agar memiliki kemampuan untuk berfikir kritis, logis dan memiliki kesadaran diri melakukan sharing problem solving dengan komunitas atau kelompok yang ada di sekitarnya terhadap permaalahan bersama yang sedang dihadapi.

Pengalaman mahasiswa belajar menyelesaikan masalah kemiskinan kota dan kemiskinan desa, melalui kegiatan kecendekian terhadap lingkungan sekitar, merupakan saah satu bentuk kontruksi belajar multi arah yaitu mahasiswa dapat belajar langsung ke masyarakat miskin marginal di kota dan desa, konsep isi kurikulum dapat berupa kegiatan belajar tematik yang ada dalam satuan atau identitas matakuliah atau sub-sub tema yang dikembangkan dosen pada kegiatan tatap muka kuliah di luar kelas.

Satuan pendidikan tinggi khususnya PTKIN dalam mengembangkan desain kurikulum pembelajaran yang memungkinkan terjadinya pembelajaran multi arah pada setiap individu, baik self-directed, collaborative, and institutional mode, maka individu atau mahasiswa dapat belajar: a) mengembangkan berfikir tingkat tinggi, b) mengembangkan harga diri, c) mengembangkan berbagai keterampilan berkomunikasi, d) mengembangkan diri trampil dalam domain digital, e) mendorong pemahaman keragaman, dan f) mengembangkan pendekatan pemecahan masalah .(Dilly Fung, 2017: 119). Keempat pendekatan tersebut tentu tidak menjadi pemisahan antar satu pendekatan dengan pendekatan yang lainnya, akan tetapi desainer kurikulum mengintegrasikan ke empat pendekatan tersebut menjadi landasan dalam merumuskan 
profil lulusan, capaian pembelajaran, bahan kajian dan satuan beban belajar yang ditetapkan pada masing-masing program studi.

Landasan desain kurikulum dalam konteks merdeka belajar dan kampus merdeka pembelajarannya menggunakan tiga strategi pembelajaran yang telah disebutkan sebelumnya akan berimplikasi pada pilihan metode pembelajaran research dan inquiry, maka secara teoritik kurikulum pembelajaran terkoneksi multi arah seperti terlihat pada gambar berikut ini:

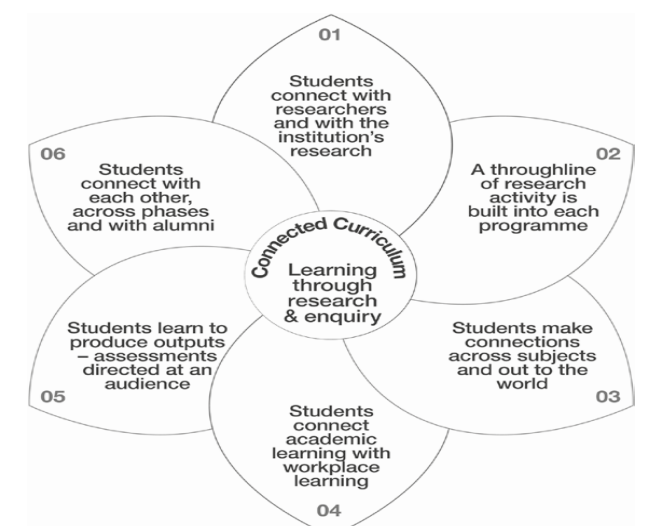

\section{Gambar 1: Desain kurikulum terkoneksi secara multi arah}

Secara oprasional bagan tersebut menunjukkan tentang konsep model belajar multi arah sebagaimana saat ini yang sedang up to date diperbincangkan kalangan pakar pendidikan yaitu "merdeka belajar dan kampus merdeka". Pertanyaan pentingnya adalah: "adakah korelasinya dengan model desain kurikulum pembelajaran KKNI yang dirancang dan ditetapkan oleh pemerintah sebagai acuan pembelajaran dan harus dijalankan oleh satuan pendidikan tersebut dapat menjangkau dan adaptif terhadap regulasi pembelajaran? Desain model kurikulum dengan menggunakan analisis keempat pendekatan tersebut maka sangat jelas dapat tercermin pada: a) profil lulusan, b) capaian pembelajaran pada program studi, c) bahan kajian, d) satuan-satuan matakuliah, e) beban belajar yang ditetapkan, f) capaian pembelajaran matakuliah, g) proses pembelajaran, dan $h$ ) bentuk penilaian, yang selanjutnya mengintegrasikan pola pengembangan MBKM dalam kegiatan belajar mahasiswa.

Kurikulum pembelajaran dengan menerapkan prinsip fleksibilitas dan integrasl dengan dinamika sosial yang ada di masyarakat, maka konsep belajar secara multi arah mahasiswa belajar menggunakan strategi "penelitian dan penyelidikan", maka kurikulum 
diusahakan terkoneksi dengan: a) para peneliti di tempat penelitiannya, b) aktifitas penelitian pada setiap program pembelajaran, c) membangun hubungan lintas subyek (komunitas) dan mengaitkannya dengan dunia luar, d) teori (ilmu pengetahuan) di kampus sesuai dengan tuntutan dunia kerja, e) belajar menciptkan produk dan mendapatkan penilaian langsung dari masyarakat atau pengguna f) kelompok atau komunitas lintas keilmuan dan para alumni.

Terkoneksi dengan a) para peneliti di tempat penelitiannya, Mahasiswa dapat beajar langsung kepada peneliti untuk mengetahui cara mengartikulasikan pertanyaan penelitian dari peneliti kepada dirinya sendiri (mahasiswa), mahasiswa dapat belajar secara aktif di lembaga riset tersebut tentang praktik penelitian dan juga aktif mengikuti praktik penelitian tersebut.

Mahasiswa belajar secara langsung dengan peneliti untuk mengetahui regulasi atau aturan tentang institusi penelitian dan program penelitian yang dapat dipelajari sesuai dengan program studi seperti lembaga riset bidang sosial ekonomi (LP3ES), SEMERU Institut, UMI Institut, mengikuti aktifitas pertemuan kelompok peneliti sehingga mendapatkan pengetahuan tentang dinamika penelitian yang dilakukan yaitu penelitian tentang pengembangan ilmu, atau penelitian teraoan untuk kepentingan pembangunan masayarakat, mahasiswa juga bisa belajar tentang: 1) pemikiran (kapasitas intelektual peneliti, 2) policy atau kebijakan riset, 3) etika praktik riset para asosiasi peneliti seperti ingin mengungkap "Tingkat Kemiskinan Masyrakat" atau "Pendapatan Masyrakat" dan sebagainya

Terkoneksi b) aktifitas penelitian pada setiap program pembelajaran, yaitu mahasiswa: 1) belajar melalui modul atau petunjuk kegiatan yang dirancang sehingga memungkinkan mereka belajar penelitian, sampai paham dan trampil melaksanakan penelitian, 2) belajar tantangan berfikir ilmiah terhadap setiap program penelitian yang dilakukan, 3) belajar secara fleksibel pada kegiatan penelitian yang diikuti dan mampu menentukan resiko keberhasilan kegiatan yang yang dikerjakan berupa portopolio hasil kerja.

Terkoneksi c) membangun hubungan lintas subyek (komunitas) dan mengaitkannya dengan dunia luar, Mahasiswa belajar berdasarkan ketentuan program studi: 1) yang mengharuskan mereka mempelajari bidang ilmu di luar disiplin yang 
sedang dipelajarinya, setidaknya satu disiplin ilmu di luar pengetahuan mereka. 2) belajar hubungan kolaboratif perspektif keilmuan seperti berkolaborasi menyelesaikan masalah sosial dari beberapa disiplin ilmu pengetahuan, 3) belajar mengatasi masalah global yang kompleks secara inerdisipliner contohnya mengatasi kemiskinan tidak cukup dengan teori sosial tetapi perlu teori psikologi, pengetahuan agama, dan ilmu sejarah dan georgrafi.

Terkoneksi d) teori (ilmu pengetahuan) di kampus sesuai dengan tuntutan dunia kerja, mahasiswa melakukan 1) belajar menganalisis pengetahuan yang dimiliki dengan kebutuhan di tempat kerja, apakah teori yang selama ini dipelajari sesuai dengan kebutuhan mereka di tempat kerja, 2) belajar tentang gagasan dan kritik atas pekerjaan professional di masayarakat melalui kegiatan temu alumni, mengikuti magang kerja para alumni yang sudah memeiliki tempat kerja, 3) Mengungkap dan melakukan sesuatu sesuai dengan pengetahuan dan keterampilan yang dimiliki terkait kegiatan penelitian untuk memberikan engalaman yang lebih luas khususnya kepada mereka (mahasiswa) yang akan mencari pekerjaan.

Terkoneksi e) belajar menciptkan produk dan mendapatkan penilaian langsung dari masyarakat atau pengguna, Mahasiswa melakukan: 1) belajar mencari penilaian atas atas produk atau hasil penelitian yang dihasilkan kepada pihak luar baik secara kangsung atau on line baik audien secara terbatas atau yang lebih luas, 2) belajar memperoleh penilaian untuk mengembangkan skill atau keahlian komunikasi dan digital, 3) belajar mendapatkan umpan balik untuk memperbaiki hasil pekerjaan yang dilakukan baik ketika tengah semester atau akhir semester di kampus masing-masing.

Terkoneksi f) kelompok atau komunitas lintas keilmuan dan para alumni yaitu mahasiswa melakukan: 1) belajar memperoleh kesempatan yang lebih banyak untuk bertemu dan berkolaborasi secara partisipatif melakukan penelitian dengan kelompok keilmuan berbeda, 2) belajar menemukan koneksi dengan kelompok lain pada tahun yang akan datang melalui model-model pendampingan, 3) belajar menemukan almni yang beragam untuk sharing dan membangun self belonging secara inklusif antar unsur pada kegiatan penelitian dan pembelajaran. 
Konsep belajar multi arah membutuhkan desain kurikulum yang didasari kebijakan lebih terbuka terhadap regulasi pengelolaan pembelajaran pada setiap kelembagaan pendidikan. Sehingga memungkinkan setiap mahasiswa memiliki kesadaran belajar secara individual dan mampu melakukan collaborative learning dengan memilih lingkungan belajar yang tepat sesuai dengan konsep kurikulum yang ditetapkan oleh program studi. Tentunya saat ini yang sedang ditunguu oleh mahasiswa adalah seberapa jauh desain kurikulum program studi memetakan isi pembelajaran yng bersinergi dengan sumber belajar secara multi arah tersebut?

Semua program studi pada satuan pendidikan dituntut mampu mengkreasi kurikulum pendidikan yang akomodatif terhadap munculnya regulasi pendidikan yang selalu dinamis dan adaptif pada tuntutan kemajuan khususnya peningkatan mutu lulusan. Konsep merdeka belajar dan kampus merdeka tidak terlalu jauh berbeda pada desain kurikulum dengan pola belajar menggunakan metode research inquiry tersebut. Ketentuan belajar setara dengan 40 SKS di luar program studi di luar kampus sebanyak 3 semester dilakukan dengan cara sebagai berikut: a) magang kerja/praktik kerja, b) proyek desa, c) mengajar di sekolah, d) pertukaran pelajar, e) penelitian/riset, f) kegiatan wirausaha, g) studi/proyek independen, h) proyek kemanusiaan. (Aris Junidi, 2020:4)

Jika diperbandingkan dengan konsep Dilly Fung yaitu terdapat enam (6) arah sumber belajar sumber belajar yang dapat dimanfaatkan oleh setiap mahasiswa melalui pendekatan belajar riset dan penyelidikan, maka konsep Nadiem makarim tentang merdeka belajar melalui delapan (8) kegiatan sebagaimana telah disebutkan di atas, bahwa terdapat tiga item penting yang tidak ada pembelajaran multi arah yaitu: 1) pertukaran pelajar, 2) mengajar di sekolah dan 3) proyek kemanusiaan. Sedangkan enam (6) unsur yang lain hakikat substansi yang dilakukan tidak terlalu jauh berbeda yaitu kegiatan belajar di luar kampus agar memperoleh pengetahuan yang lebih komprehensif. Oleh karenanya jika ditelusuri secara mendalam maka sumber $A$ Connected Curriculum for Higher Education merupakan embrio yang memberikan inspirasi munculnya konsep MBKM yang saat ini menjadi salah satu diantara topik pembicaraan yang sedang up to date dalam memperbaiki kinerja pendidikan tinggi untuk menghasilkan mutu lulsan yang berdaya saing, salah satunya pada aspek "development of student" employbility dan berkarakter ke-Indonesia-an dalam menyongsong Indonesia Emas 20045 sebagai 
generasi penerus bangsa yang memiliki ciri: 1) kritis 2) kreatif, 3) komunikatif, dan 4) kolaboratif yang mampu menghadapi tantangan perubahan dan tuntutan kemajuan peradaban dengn penuh persaingan antar elemen bangsa baik di dalam negeri atau pun luar negeri.

Pola belajar yang didasarakan atas kesadaran diri dalam belajar (learning how to learn) mereka diarahkan untuk mencapai kompetensi untuk memenuhi tugas hidup yang tidak ringan sesuai dengan tantangan kehidupan abad 21 untuk memeiliki kompetensi personal seperti: a) critical thinking, b) creatifity thinking, c) public communication, d) collaboration humanities,".

\section{Implikasi Belajar Multi Arah dan Capaian Pembelajaran Mahasiswa}

Konsep belajar yang lazim dikenal oleh setiap individu adalah aktifitas interaksi educatif secara fisik dan psikologis terhadap isi pembelajaran dan pengalaman serta lingkungan sosial yang mengitarinya didesain untuk mencapai tujuan belajar anak atau mahasiswa. Belajar multi arah dengan kurikulum pembelajaran yang terintegrasi dengan berbagai sumber belajar yang dipersiapkan di lingkungan pendidikan atau di luar lembaga pendidikan tinggi tersebut, pola belajar yang dilakukan melalui self directed learning atau pun collaborative learning, and institutional mode melalui desain kurikulum yang terintegrasi dengan tuntutan belajar merdeka tidak hanya mencukupkan kegiatan tatap muka di kampus saja, akan tetapi terdapat kegiatan pembelajaran di luar kampus untuk meningkatkan hasil belajar yang lebih komprehensif, yaitu mahasiswa memiliki pengalaman belajar yang konkrit sesuai dengan: a) tuntutan bidang kerja di masyarakat, b) integrasi keilmuan lintas bidang atau interdisipliner/multidisipliner, c) pengembangan diri untuk belajar membuat produk ilmu pengetahuan.yang mendapatkan respon penilaian dari masyarakat.

Tuntutan bidang kerja merupakan kebutuhan dasar yang perlu diperhatikan oleh setiap penyelenggara pendidikan tinggi, bahwa konsep link and match antaras dunia kerja dan dunia industry dengan pendidikan merupakan sesuai dengan kompetensi keilmuan yang dipelajari di bangku perkuliahan baik melalui tatap muka kuliah, atau kegiatan di luar kampus dengan berbagai sumber belajar yang bermanfaat untuk 
mengembangkan skill melakukan pekerjaan yang ada di tengah masyarakat, pengembangan mahasiswa tersebut disebut "development of student" employability skill. merupakan salah diantara aspek penting untuk dikembangkan oleh pendidikan tinggi terhadap mahasiswa, agar teori dan ilmu pengetahuan yang dipelajari dapat berkembang dan bermanafaat untuk menciptakn lapangan pekerjaan wirausaha mandiri), mendapatkan pekerjaan yang ada di masyarakat, menyelesaikan problem dirinya sendiri dan problem sosial lain yang dihadapi masyarakat.

Makna emploibility skill yaitu: are those basic skills necessary for getting, keeping, and doing well on a job, .(Jaquelyn P. Robinson, 2000:1). kalimat tersebut memiliki makna yaitu keterampilan dasar-dasar dalam bekerja yang diperlukan untuk mencari atau mendapatkan pekerjaan, dan memelihara pekerjaan tersebut dengan cara bekerja yang baik. Tuntutan kemampuan kerja calon lulusan pendidikan tinggi merupakan keniscayaan yang tidak dapat dielakkan, sebab bahwa layanan sistem pendidikan dituntut berorientasi pada kemampuan bidang kerja yang dibutuhkan oleh masyarakat, oleh karena itu wajar jika setiap layanan pendidikan tinggi berorientasi dunia kerja. Konsep pemerintah melakukan terobosan pemikiran pendidikan bahwa link and macth antara keduanya yaitu dunia pendidikan tidak boleh teraleniasi dari lingkungan sosial atau masyarakat yang ada di sekitarnya.

Pendidikan pada level perguruan tinggi pada hakekatnya tidak hanya sekedar membentuk atau meluluskan sumbedaya manusia siap bekerja, akan tetapi juga mewujudkan manusia khususnya di Indonesia yang memiliki kompetensi kewirausahaan. Kemampuan setiap individu untuk menciptakan peluang-peluang kerja mandiri yang dapat menghasilkan karya usaha untuk memenuhi kebutuhan hidupnya dan atau berkolaborasi menciptakan lapangan kerja bagi sesama lulusan yang membutuhkan pekerjaan wirausaha.

Pekerjaan wirausaha menjadi pilihan untuk menepis kegagalan pendidikan tinggi menjawab pertanyaan public, bahwa selama ini terjadi penumpukan sumbedaya manusia terdidik kurang mampu dan sulit terserap pada dunia kerja, baik pada dunia usaha atau dunia industry (DUDI), realitas tersebut didukung fakta yaitu: ketika pemerintah membuka peluang rekruitmen Calon Pegawai Negeri Sipil, mereka ribuan atau jutaan calon pekerja baru antri berburu mencari peluang kerja di sektor formal (pemerintah). Dalam kaitan ini 
perlu mencoba alternatif penyiapan sumberdaya manusia lewat pendidikan, akankah terjadi perubahan yang besar jika perguruan tinggi menyematkan identitas diri menjadi entrepreneur university?, setiap perguruan tinggi memanfaatkan semua unsur internal yaitu SDM, finansial, dan seluruh komponen yang terlihat menjadi pusat kewirausahaan, dan mencitptakan hubungan timbal balik dengan stake holder menjadi suatu tindakan konkrit untuk mendudkung kurikulum keiwausahaan perguruan tinggi, seperti organisasi bisnis, komunitas masyarakat (alumni), pemerintah, dan industri, .(Yulizar Kasih, 2013: 164-182).

Mewujudkan sumberdaya manusia produk pendidikan tinggi menjadi pekerja yang akan mengisi peluang peluang kerja di masyarakat dan menjadi pengusaha atau wirausaha adalah sebagian dari tugas dan tanggungjawab pendidikan tinggi yang memiliki komitmen untuk peningkatan kualitas lulusan agar tidak terjadi gap antara pendidikan tinggi dan kebutuhan masayarakat tentang peluang kerja dan peluang mencipatakan usaha-usaha baru dari generasi wirausahawan baru hasil pendidikan tinggi. Konsep employment dan konsep entrepreneur dua hal berbeda tetapi menjadi kesatuan identitas lulusan yang melekat dalam memilih salah satunya untuk dikembangkan setelah memperoleh pendidikan di pendidikan tinggi.

Problem utama pendidikan tinggi adalah tidak semua institusi tersebut mampu melakukan terobosan secara sistemik untuk menginovasi pendidikan yang memberikan kontribusi kuat lahirnya sumberdaya manusia untuk memperoleh pengetahuan atau teori dan pengalaman yang sukup baik terhadap skill employment dan entrepreneur yang memadai dari lembaga pendidikan tersebut sebab: a) banyak ragam pendidikan tinggi yang dikelola oleh perintah, masyarakat, b) ragam program studi dan bentuk pendidikan seperti akademik, profesi, dan vokasi, c) regulasi yang selalu berusah-ubah dari pemangku kejibakan, sehingga muncul adagium "berganti menteri ganti kebijakan pendidikan". ketiga unsur ini berdampak pada pengelolaan pendidikan semakin sulit untuk mengfokuskan pada orientasi yang jelas-jelas sesuai dengan kebutuhan pasar.

Problem utama tentang upaya terbentuknya employment skill dan entrepreneur, tidak jarang dialami oleh mahasiswa itu sendiri, bahwa mahasiswa ketika belajar di perguruan tinggi mengalami evoria identitas kemahasiswaan mereka adakalanya: a) 
kecepatan dan ketepatan melakukan adaptasi mengalami hambatan, b) mengalami disorientasi ketika bertemu dengan sesama mahasiswa mengikuti aktifitas kemahasiswaan sehingga lupa orientasi akademiknya, c) kompetensi akademik dan kemampuan akademik yang rendah sehingga menyebabkan gagal menemukan jati diri kemahasiswaannya.

Kedua problem baik yang bersumber dari program layanan pendidikan yang kurang terfokus pada aspek perolehan pengetahuan dan pengalaman employment skill dan entrepreneur, ataupun yang problemnya bersumber dari mahasiswa itu sendiri, maka diperlukan suatu usaha yang benar-benar mampu membawa mahasiswa belajar secara multi arah dan implementasinya melalui model merdeka belajar dan kampus merdeka, sehingga setiap mahasiswa dituntut untuk belajar secara terencana agar memiliki: a) kemampuan berpikir kreatif, kritis, dan inovatif, dan sensitivitas interdisipliner. dan multidisipliner, b) penguasaan teknologi komunikasi dan kemampuan riset dunia maya, c) receptive mind dan multikulturalism, d) kerja sama tim, e) negosiasi, dan mobilitas geografis, f) kemampuan komunikasi yang efektif, g) think globally, act locally, dan collaborate internationally g) keterampilan science of data, (Mayli Oi-Gardiner \& et al, 2017: 113).

Memposisikan mahasiswa sebagai pembelajar yang menyadari tentang belajar itu sendiri learning how to learn based on self awareness dalam berbagai aktifitas pembelajaran dan program yang ditawarkan oleh satuan pendidikan tinggi, maka sangat memungkinkan akan terjadi perubahan secara significan bahwa mahasiswa ketika lulus nanti mampu: menjadi tenaga ahli/professional, dan ilmuwan plus wirausaha, (Mayli OiGardiner \& et al, 2017: 53).

Salah satu diantara konstruksi belajar multi arah dalam implementasi merdeka belajar kampus merdeka maka bentuk belajar yang harus dilakukan oleh mahasiswa adalah: out-of-class experiences were somewhat more important to development of critical thinking than in class-experiment, (Harvey, Lee \& Knight, Peter T, 1966:148) Mahasiswa atau calon lulusan melalui model enquiry/research atau model merdeka belajar pada kampus merdeka, sebab mereka dapat menemukan sumber yang lebih variatif di dalam dan atau di luar kampus sehingga mereka akan memiliki pengetahuan 
dan pengalaman dalam melakukan employment skill dan entrepreneur melalui proses pembelajaran di perguruan tinggi.

Mahasiswa melaluai aktifitas pembelajaran secara enquiry baik self directed learning atau collaborative learning belajar pengetahuan teoritik, praktik-praktik kerja di dunia usaha atau dunia insdustri, dan kegiatan "praktek wirausaha terbimbing bersama mentor". Kegiatan belajar praktik belajar lapangan tersebut hakekatnya merupakan media terbangunnya kemampuan berfikir kritis untuk mempersiapkan diri menghadapi tuntutan profesi/keahlian kerja di masyarakat, dan/atau merealisasikan kemampuan kerja wirausaha yang dimiliki dengan menciptakan lapangan kerja mandiri, serta berkontribusi inspiratif menyelesaikan problem sosial yang dihadapi masyarakat.

\section{Penutup}

Konstruksi belajar multi arah, sebagaimana yang telah dibahas di atas dapat disimpulkan bahwa:

1. Konstruksi belajar multi arah yang menggagas keterlibatan mahasiswa secara selfdirected, collaborative, and institutional mode sebagai pendekatan pembelajaran, berorientasi pada upaya meningkatkan kapasitas mahasiswa menjadi lulusan yang mampu mengaplikasikan bidang keilmuan dan skill praktis dalam dunia kerja yaitu memanfaatkan sumber belajar yang luas dengan model pembelajaran research atau inquiry atau melalui model merdeka belajar dan kampus merdeka, sesuai dengan karakteristik institusi yang desain kurikulumnya memantik terjadinya pola pembelajaran multi arah dan mahasiswa mampu menganalisis learning how to learn nya sesuai dengan kebutuhan belajar mahasiswa.

2. Implementasi strategi pembelajaran multi arah membutuhkan desain kurikulum pendidikan tinggi yang adaptif sesuai dengan tuntutan perubahan regulasi kekinian dan kebutuhan masa depan sebagaimana dalam desain kurikulum kualifikasi nasional Indonesia yaitu tuntutan dunia usaha dan dunia industri serta kewirausahaan mandiri yang menghasilkan lapangan pekerjaan baru.

3. Dampak implementasi konstuksi pembelajaran multi arah salah satu diantara bentuk hasil pembelajaran yang diperoleh oleh mahasiswa yaitu employment skill dan 
enterprneur berlandaskan nilai-nilai karakter komunitas yang ada dalam kultur kehidupan masyarakat.

4. Employment skill dan entrepreneur di dalamnya mengandung unsur critical think yang dimiliki mahasiswa merupakan kapasitas atau potensi diri sehingga mereka (mahasiswa) mampu: berfikir kritis, berfikir kreatif, berkomunikasi efektif dengan orang lain, dan berkolaborasi bersama kolega atau tim kerja.

\section{Saran}

Saran-saran yang dapat disampaikan penulis yaitu:

1. Mahasiswa sebagai obyek dan atau subyek pembelajar dituntut untuk memperkuat perolehan pengetahuan dan pengalaman di lingkungan pendidikan, mahasiswa hendaknya mendesain pola pembelajaran baik on lline system atau tatap muka yang kontruksinya belajar dari berbagai arah sumber dan tempat beajarnya.

2. Dosen henaknya selalu menggunakan strategi pembelajarn yang variatif salah satunya strategi belajar yang memanfaatkan berbagai sumber dari multi arah yang mendorong mahasiswa dapat self directed learning, collaborative, dan atau institutional learning.

\section{Referensi}

Aris Junaidi. (2020). Arah Kebijakan Pendidikan Tinggi Saat Ini dan Era 5.0. Jakarta: Sekretariat Kemendikbud. RI.

B. Seels \& Richey, R.C. (1994). Instructional Technology: The Definition and Domains of the Field. AECT.

Dilly Fung. (2017). A Connected Curriculum for Higher Education. London, UCL Press, 119.

Direktorat Jendral Pendidikan Tinggi Kementerian Pendidikan dan Kebudayaan. (2020). Buku Saku Panduan Merdeka Belajar Kampus Merdeka. Jakarta: Direktorat Jendral Pendidikan Tinggi Kementerian Pendidikan dan Kebudayaan.

Harvey, Lee \& Knight, Peter T. (1966). Transforming Higer Education. Society for Research in to Higher Education. 
Jaquelyn P. Robinson. (2000). What Are Emploibility Skill. The Workplace: Alabama Cooperative Extention System, 1(3), 1.

Jerold W. Apps. (1979). Problem in Continuing Education. Book Company.

Mamat Burhanuddin. (2020). Pembelajaran Kampus Merdeka di PTKI. Jakarta: Direktorat

Pendidikan Tinggi Keagamaa Islam Direktorat Jendral Pendidikan Islam Kementerian Agama RI.

Mayli Oi-Gardiner \& et al. (2017). Era Disrupsi: Peluang dan Tantangan Pendidikan Tinggi di Indonesia. Jakarta: Akademi Ilmu Pengetahuan Indonesia.

Peter Jarvis \& John Holford, Collin Griffin. (1988). The Theory and Practice of Learning. Kogan Page.

Ramli Abdullah. (2012). Pembelajaran Berbasis Pemanfaatan Sumber Belajar. Jurnal Ilmiah Didaktika, Volume X, 216-231.

Robert M. Smith. (1982). Learning How to Learn: Applied Teory for Adult. Follet Publishing Company.

Rusman. (2008). Manajemen Kurikulum. Bandung: Raja Grafindo Utama.

Yulizar Kasih. (2013). Mewujudkan Pendidikan Kewirausahaan di Perguruan Tinggi Melalui Proses Pembelajaran Berkelanjutan. Jurnal IImiah STIE MDP:Forum Bisnis Dan Kewirausahaan, 2(2), 164-182.

Yusuf Hadi Miarso. (2005). Menyemai Benih Teknologi Pendidikan. Bandung: Kencana. 